\title{
Penentuan Variabel Berpengaruh Terhadap Pengembangan Kampung Cerdas dalam Mewujudkan Konsep Smart City
}

\author{
Dewi Anggraeni Paramasatya dan Dian Rahmawati \\ Departemen Perencanaan Wilayah dan Kota, Fakultas Teknik Sipil dan Perencanaan, Institut \\ Teknologi Sepuluh Nopember (ITS) \\ e-mail:dnrahmawati@gmail.com
}

\begin{abstract}
Abstrak-Kota Surabaya merupakan salah satu kota metropolis di Provinsi Jawa Timur dengan pengembangan kota menuju smart city. Salah satu hal yang mendominasi pengembangan sebuah kota ialah permukiman, dimana Kota Surabaya memiliki luasan lahan permukiman mencapai 16.051,51 Ha atau 49\% dari luas wilayah Kota Surabaya berdasarkan RTRW Kota Surabaya Tahun 2014-2034. Dewasa ini, disparitas bermukim sering kali dijumpai akibat salah persepsi mengenai permukiman informal. Dimana kampung bukan merupakan permukiman liar maupun permukiman kumuh, melainkan bentuk permukiman swadaya yang dibangun oleh para penghuninya tanpa mengikuti ketentuan-ketentuan pembangunan bangunan formal dari pemerintah berdasarkan Bappeko (2012). Kampung perkotaan menjadi ciri khas yang dimiliki Kota Surabaya untuk dipertahankan dengan memanfaatkan kondisi pengembangan kota yang cukup pesat menuju smart city. Penelitian ini bertujuan untuk menentukan variabel berpengaruh dalam pengembangan kampung cerdas di Kota Surabaya dalam mewujudkan konsep smart city. Penelitian ini mengunakan teori perumahan dan permukiman, serta kota cerdas yang diadaptasi sesuai kebutuhan penelitian yaitu terhadap permukiman. Adapun alat analisis yang digunakan dalam penelitian ini ialah Analisis Deskriptif Kualitatif untuk mengeksplorasi potensi terhadap kampung dalam menerapkan konsep cerdas dan Analisis Faktor Konfirmatori (CFA) yang digunakan untuk menentukan variabel berpengaruh terhadap kecerdasan kampung. Dari hasil penelitian ini terdapat variabel berpengaruh sesuai sub konsep dimensi smart city, yang mana variabel berpengaruh menyesuaikan karakter kampung perkotaan dan masyarakat didalamya. Adapun variabel berpengaruh pada lokasi penelitian yakni: terkait keberadaan industri dan entrepreneurship, adanya kontribusi ekonomi terhadap kawasan sekitar, kondisi sadar teknologi dan penggunaan internet, tersedianya sarana dan prasarana lingkungan, adanya koordinasi masyarakat mengenai lingkungan, tingkat pendidikan, keberagaman kegiatan, open mind, terkait kondisi kriminilitas, adanya fasilitas bangunan umum, kesehatan, serta pendidikan, kondisi masyarakat, jumlah pelayanan pemerintah dan akses dalam menggunakan, serta tanggapan masyarakat terhadap pelayanan tersebut.
\end{abstract}

Kata Kunci-Perumahan dan permukiman, Kampung Perkotaan, Smart City, CFA.

\section{PENDAHULUAN}

TNDONESIA merupakan negara berkembang yang mana Lerusaha meningkatkan taraf hidup manusianya disegala aspek. Sesuai dengan kegiatan yang diadakan PBB yaitu The Sustainable Development Goals atau yang biasa kita singkat sebagai SDGs, melanjutkan agenda dunia pembangunan untuk kemaslahatan manusia dan planet bumi yakni SDGs. Indonesia ikut berpartisipasi dalam penerapan program SDGs. Sejalan dengan poin SDGs nomor 11 yaitu kota dan komunitas berkelanjutan, dimana membuat kota dan permukiman yang inklusif, aman, berdaya tahan, dan berkelanjutan (Konvergensi Agenda Pembangunan: Nawa Cita, RPJMN, dan SDGs, 2015) [1].

Kota Surabaya ini merupakan salah satu kota di Indonesia yang pengembangan kotanya menuju smart city dibidang permukiman. Dimana banyak dijumpainya kampung perkotaan yang tetap berusaha menjaga eksistensi kawasan ditengah perkembangan kota menuju metropolitan. Dengan kondisi tersebut pengembangan permukiman dan infrastruktur perkotaan yang kurang atau belum mengantisipasi dan mengakomodir fenomena perkembangan aktifitas perkotaan yang ada [2]. Kampung perkotaan ini perlu dimanfaatkan untuk menjadi ciri khas atau keunggulan pengembangan kota, dimana tidak mengesampingkan komponen asal mula Kota Surabaya sekarang ini. Pembangunan berkelanjutan ini tidak bisa dipisahkan dari konsep kota cerdas atau smart city. Konsep kota cerdas ini sebagai upaya penerapan dari pembangunan berkelanjutan. Kota cerdas merupakan konsep kota yang menggunakan pemanfaatan teknologi informasi dan komunikasi (TIK) untuk menghubungkan, untuk pemantauan dan pengendalian berbagai sumber daya yang ada di dalam kota secara efektif dan efisien dalam rangka memaksimalkan pelayanan kepada warga kota (Alawadhi et al., 2012) [3].

Surabaya dikenal dengan potensi pengembangan permukiman kota dengan prestasi tingkat dunia. Hal ini merupakan kesempatan dalam perwujudan kota Surabaya menuju smart city melalui bidang permukiman. Kawasan pemukiman yang berada di tengah kota dan dikelilingi gedung-gedung bertingkat dan pusat bisnis merupakan kawasan yang cukup menarik untuk diteliti [4]. Kampung perkotaan Surabaya ini menjadi daya tarik tersendiri, dimana 
dalam pengembangan kota kearah metropolitan, Kota Surabaya tidak mengesampingkan keberadaan dari kampung perkotaan. Kota Surabaya telah memiliki konsentrasi khusus dalam pengembangan kampung perkotaan, dimana kampungkampung tersebut telah dibina dan telah dijadikan kampung percontohan yang mana bergerak dan berkembangan secara mandiri dengan pengawasan yang dilakukan oleh pemerintah kota. Meliputi lokasi penelitian yaitu pada Kampung Margo Rukun dan Kampung Lawas Maspati [5], yang mana menjadi kampung percontohan saat ini. Kampung perkotaan ini memiliki keragaman bidang unggulan yang ditekuni, baik dibidang ekonomi, sosial, maupun budaya, dimana kebutuhan penembangan kampung perlu disesuaikan dengan karakter kampung tersebut. Dimana perlu ditentukan suatu standar untuk melihat ciri-ciri kampung perkotaan di Kota Surabaya ini, agar berdaya tahan tidak hanya mengandalkan satu keunggulan bidang saja. Untuk mewujudkan hal tersebut, diperlukannya menentukan variabel berpengaruh terhadap pengembangan kampung cerdas dalam mewujudkan konsep smart city.

\section{METODE PENELITIAN}

\section{A. Jenis dan Pendekatan Penelitian}

Pendekatan yang digunakan dalam penelitian ini adalah pendekatan rasionalistik. Jenis penelitian dalam penelitian ini adalah mix method yakni prosedur untuk mengumpulkan, menganalisis dan "menggabungkan" penelitian kuantitatif dan kualitatif dan penelitian kuantitatif dan kualitatif dan metode dalam satu studi untuk memahami masalah. Diasumsikan, penggunaan kedua metode kuantitatif dan kualitatif, dalam kombinasi akan memberikan pemahaman lebih baik pada masalah dan pertanyaan penelitian daripada metode tersebut berdiri sendiri.

\section{B. Variabel Penelitian}

Variabel penelitian yang digunakan ialah adaptasi dari teori kota cerdas dan disesuaikan dengan bidang permukiman di Kota Surabaya, yang mana didapati sebagai berikut. Jenis dan jumlah industri, kondisi industri, jenis dan jumlah entrepreneurship, kondisi entrepreneurship, tingkat kreativitas/inovasi usaha, kondisi lokasi studi, adanya kontribusi ekonomi terhadap lingkup administrasi lainnya, kondisi sadar teknologi, kondisi penggunaan internet, kondisi sarana, kondisi prasarana, kondisi jalan, kondisi kendaraan yang melewati, kondisi peraturan yang diterapkan pada kawasan, tersedianya sarana, tersedianya prasarana, adanya koordinasi warga mengenai pengelolaan lingkungan, tingkat pendidikan, jenis dan jumlah macam kegiatan, kondisi kegiatan yang ada, open mind, jenis dan jumlah pelaporan terkait kriminalitas, kondisi kriminalitas, fasilitas kesehatan, fasilitas pendidikan, fasilitas bangunan umum, kondisi kegiatan wisata, kondisi integrasi sosial dengan wilayah berbatasan, kondisi masyarakat, jumlah pelayanan pemerintah via online, jumlah pengakses atau pengunjung laman pelayanan pemerintah, serta kondisi tanggapan masyarakat atas pelayanan pemerintah via online [6].
C. Mengidentifikasi potensi permukiman cerdas pada kampung tematik di Kota Surabaya dalam mewujudkan Smart City

Analisis deskriptif kualitatif adalah analisis yang digunakan untuk memberikan gambaran mengenai potensi wilayah studi secara mendalam disertai dengan pembahasan - pembahasan yang disesuaikan dengan teori - teori terkait. Analisis ini menjabarkan secara ringkas mengenai hal mendasar bagi tiap variabel data yang dimiliki pada kategori di setiap indikator dan konsep dimensi. Data yang dikumpulkan tersebut perlu disajikan dengan komunikatif dan informatif agar mudah dimengerti oleh pihak lain. Data potensi yang dihasilkan nantinya akan bersifat spesifik dan dapat di komparasikan terhadap variabel di tiap permukiman sesuai dengan potensi yang berbeda antar satu permukiman dengan yang lainnya.

D. Pemetaan perseptual terhadap preferensi permukiman cerdas pada kampung tematik di Kota Surabaya dalam mewujudkan Smart City

Confirmatory Factor Analysis digunakan untuk mengidentifikasi faktor-faktor yang berpengaruh terhadap penentuan kriteria kampung cerdas di Kota Surabaya, selanjutnya analisis ini akan mereduksi beberapa variabel yang tidak digunakan dalam penelitian [7]. Confirmatory Factor Analysis menggunakan bantuan software SmartPLS 3.0 dengan tahapan-tahapan dalam analisis sebagai berikut.

1. Pengelompokan variabel berdasarkan faktor yang sesuai dengan tinjauan pustaka.

2. Melakukan analisis setiap faktor dengan menggunakan bantuan software SmartPLS 3.0, faktor-faktor dalam variabel penelitian dapat dikatakan valid ketika syarat uji validitas, uji reliabitas, dan uji signiikansi memenuhi. Adapun syarat yang harus dipenuhi pada uji validitas (nilai standardize loading factor diatas 0,5 dapat diterima), uji reliabilitas (nilai cronbach's alfa $\geq 0.5$, nilai composite reliability $\geq 0.7$, serta nilai $\mathrm{AVE} \geq 0.5$ ), dan uji signifikansi ( $\mathrm{p}$-values $\leq 0.05$ dan nilai t-statistic $\geq 1.96$ ), sedangkan jika nilai-nilai tersebut tidak terpenuhi maka faktor tersebut tidak valid.

\section{HASIL DAN DISKUSI}

A. Mengidentifikasi potensi permukiman cerdas pada kampung tematik di Kota Surabaya dalam mewujudkan Smart City

Dalam mengidentifikasi potensi permukiman cerdas di Kota Surabaya maka digunakan teknik analisa deskriptif kualitatif. Dalam penggunaannya, teknik ini membandingkan kondisi eksisting dengan standar yang berlaku dari suatu teori maupun literatur terkait pada setiap variabel.

Adapun kampung yang dijadikan lokasi studi memberikan hasil yang disesuaikan dengan variabel penelitian sebagai berikut. Kampung Margo Rukun memiliki keberagaman jenis aktifitas ekonomi, tersedianya sarana dan prasarana lingkungan yang baik, terjangkaunya jarak terhadap fasilitas umum, namun kampung ini memiliki aksesibilitas yang rumit, serta kesadaran teknologi (internet) yang masih kurang serta minimnya sarana umum pada kampung dikarenakan lahan yang minim, serta peran masyarakat yang kurang dalam hal tour guide lokal, program pemberdayaan, dan pengolahan 
produk khas. Kampung Lawas Maspati memiliki keberagaman jenis aktifitas ekonomi, tersedianya sarana dan prasarana lingkungan dan umum yang baik, terdapatnya sarana umum pada kampung meskipun lahan yang minim, lokasi kampung yang ada pada pinggir jalan besar membuat aksesibilitas mudah dijangkau, sadar akan teknologi yang baik oleh masyarakat kampung, peran masyarakat yang baik dalam hal tour guide lokal, program pemberdayaan, dan pengolahan produk khas, namun kampung ini masih kurang terjangkaunya mengenai jarak terhadap fasilitas umum.

B. Mengidentifikasi variabel yang berpengaruh berdasarkan preferensi masyarakat kampung cerdas di Kota Surabaya dalam mewujudkan konsep smart city

Adapun proses identifikasi variabel berpengaruh ini membutuhkan input data berupa gambaran mengenai lokasi penelitian dimana data tersebut didapatkan melalui kuesioner CFA yang telah dibagikan pada masyarakat pada kampung tertuju. Partisipasi masyarakat memiliki peranan penting dalam upaya peningkatan kualitas hidup [8]. Adapun proses ini yaitu Analisis Faktor Konfirmatori dibantu dengan menggunakan software SmartPLS 3.0 pada dua kampung dengan melalui tahapan uji validitas, uji reliabilitas, dan uji signifikansi sebagai berikut.

Tabel 1

Uji Validitas pada Kampung Margo Rukun

\begin{tabular}{|c|c|c|c|c|c|c|}
\hline & Smart Economy & $\begin{array}{c}\text { Smart } \\
\text { Environment }\end{array}$ & $\begin{array}{c}\text { Smart } \\
\text { Governance }\end{array}$ & Smart Living & Smart Mobility & Smart People \\
\hline SEC1 & 0.582 & & & & & \\
\hline & & & & & & \\
\hline SEC3 & 0.868 & & & & & \\
\hline SEc4 & 0.833 & & & & & \\
\hline SEC5 & & & & & & \\
\hline $\begin{array}{l}\text { SEC6 } \\
\text { SEC7 }\end{array}$ & 0.561 & & & & & \\
\hline SEn 1 & & 0.825 & & & & \\
\hline SEn2 & & 0.88 & & & & \\
\hline SEn3 & & & & & & \\
\hline SG1 & & & 0.944 & & & \\
\hline SG2 & & & 0.966 & & & \\
\hline SG3 & & & & & & \\
\hline $\begin{array}{ll}\text { SL1 } \\
\text { S12 }\end{array}$ & & & & & & \\
\hline$\frac{S \text { SL2 }}{\text { SL3 }}$ & & & & 0.715 & & \\
\hline SL4 & & & & 0.656 & & \\
\hline SL5 & & & & & & \\
\hline SL6 & & & & & & \\
\hline SL7 & & & & & & \\
\hline $\begin{array}{ll}S L 8 \\
591\end{array}$ & & & & 0.818 & & \\
\hline$\frac{S M 1}{\text { SM12 }}$ & & & & & 0.903 & \\
\hline$\frac{S^{S M 2}}{\text { SM3 }}$ & & & & & 0.88 & \\
\hline$\frac{5 M 3}{\text { SM4 }}$ & & & & & & \\
\hline$\frac{3 N 44}{S M 5}$ & & & & & & \\
\hline SM6 & & & & & & \\
\hline SM7 & & & & & & \\
\hline SP1 & & & & & & 0.647 \\
\hline SP2 & & & & & & 0.723 \\
\hline SP3 & & & & & & \\
\hline SP4 & & & & & & 0.847 \\
\hline
\end{tabular}

Tabel 2.

Uji Validitas pada Kampung Lawas Maspati

\begin{tabular}{|c|c|c|c|c|c|c|}
\hline & Smart Economy & $\begin{array}{c}\text { Smart } \\
\text { Environment }\end{array}$ & $\begin{array}{c}\text { Smart } \\
\text { Governance }\end{array}$ & Smart Living & Smart Mobility & Smart People \\
\hline SEC1 & 0.828 & & & & & \\
\hline SEc2 & 0.688 & & & & & \\
\hline SEc3 & 0.735 & & & & & \\
\hline SEC4 & 0.785 & & & & & \\
\hline \multirow{2}{*}{\multicolumn{7}{|c|}{ SEC5 }} \\
\hline \multirow{2}{*}{\multicolumn{7}{|c|}{$\begin{array}{l}\text { SEC6 } \\
\text { SECC }\end{array}$}} \\
\hline & & & & & & \\
\hline \multicolumn{7}{|l|}{$\frac{\text { SEC7 }}{\text { SEn1 }}$} \\
\hline \multicolumn{7}{|l|}{$\frac{\operatorname{Sen} 1}{\operatorname{SEn} 2}$} \\
\hline SEn3 & & 1 & & & & \\
\hline 561 & & & 0.869 & & & \\
\hline 562 & & & 0.799 & & & \\
\hline $5 \mathrm{GG3}$ & & & 0.725 & & & \\
\hline SL1 & & & & 0.805 & & \\
\hline $\mathrm{SL2}$ & & & & 0.745 & & \\
\hline \multicolumn{7}{|l|}{ St3 } \\
\hline \multicolumn{7}{|l|}{ SL4 } \\
\hline SLL & & & & 0.525 & & \\
\hline \multicolumn{7}{|l|}{ SL6 } \\
\hline \multicolumn{7}{|l|}{517} \\
\hline SL8 & & & & 0.804 & & \\
\hline SM1 & & & & & 0.94 & \\
\hline SM2 & & & & & 0.937 & \\
\hline \multicolumn{7}{|l|}{ SM3 } \\
\hline \multicolumn{7}{|l|}{ SM4 } \\
\hline \multirow{2}{*}{\multicolumn{7}{|c|}{ SM5 }} \\
\hline \multicolumn{3}{|l|}{ SM7 } & & & & \\
\hline & & & & & & 1 \\
\hline \multicolumn{7}{|l|}{ SP2 } \\
\hline SP3 & & & & & & \\
\hline SP4 & & & & & & \\
\hline
\end{tabular}

Tabel 3

Uji Reliabilitas pada Kampung Margo Rukun

\begin{tabular}{|c|c|c|c|}
\hline & Cronbach's Alpha & Composite Reliability & $\begin{array}{c}\text { Average Variance } \\
\text { Extracted (AVE) }\end{array}$ \\
\hline Smart Economy & 0.689 & 0.81 & 0.525 \\
\hline Smart Environment & 0.627 & 0.842 & 0.727 \\
\hline Smart Governance & 0.905 & 0.954 & 0.912 \\
\hline Smart Living & 0.575 & 0.775 & 0.537 \\
\hline Smart Mobility & 0.742 & 0.886 & 0.795 \\
\hline Smart People & 0.587 & 0.786 & 0.553 \\
\hline
\end{tabular}

Tabel 4.

Uji Reliabilitas pada Kampung Lawas Maspati

\begin{tabular}{|c|c|c|c|}
\hline & Cronbach's Alpha & Composite Reliability & $\begin{array}{c}\text { Average Variance } \\
\text { Extracted (AVE) }\end{array}$ \\
\hline Smart Economy & 0.759 & 0.845 & 0.579 \\
\hline Smart Environment & 1 & 1 & 1 \\
\hline Smart Governance & 0.717 & 0.842 & 0.64 \\
\hline Smart Living & 0.697 & 0.816 & 0.532 \\
\hline Smart Mobility & 0.864 & 0.936 & 0.881 \\
\hline Smart People & 1 & 1 & 1 \\
\hline
\end{tabular}

Tabel 5.

Uji Signifikansi pada Kampung Margo Rukun

\begin{tabular}{|c|c|c|c|c|}
\hline Variabel & $\begin{array}{c}\text { Original Sample } \\
\text { (O) }\end{array}$ & $\begin{array}{c}\text { Standard } \\
\text { Deviation (STDEV) }\end{array}$ & $\begin{array}{c}\text { T Statistics } \\
(\text { O/STDEV } /)\end{array}$ & P Values \\
\hline SEc1 & 0.582 & 0.26 & 2.24 & 0.026 \\
\hline SEc3 & 0.868 & 0.217 & 3.993 & 0 \\
\hline SEC4 & 0.833 & 0.196 & 4.241 & 0 \\
\hline SEC7 & 0.561 & 0.185 & 3.029 & 0.003 \\
\hline SEn1 & 0.825 & 0.088 & 9.342 & 0 \\
\hline SEn2 & 0.88 & 0.062 & 14.09 & 0 \\
\hline SG1 & 0.944 & 0.397 & 2.377 & 0.018 \\
\hline SG2 & 0.966 & 0.347 & 2.781 & 0.006 \\
\hline SL3 & 0.715 & 0.09 & 7.938 & 0 \\
\hline SL4 & 0.656 & 0.197 & 3.324 & 0.001 \\
\hline SL8 & 0.818 & 0.061 & 13.51 & 0 \\
\hline SM1 & 0.903 & 0.094 & 9.592 & 0 \\
\hline SM2 & 0.88 & 0.085 & 10.407 & 0 \\
\hline SP1 & 0.647 & 0.177 & 3.657 & 0 \\
\hline SP2 & 0.723 & 0.153 & 4.739 & 0 \\
\hline SP4 & 0.847 & 0.072 & 11.802 & 0 \\
\hline
\end{tabular}


Tabel 6.

Uji Signifikansi pada Kampung Margo Rukun

\begin{tabular}{|c|c|c|}
\hline No & $\begin{array}{l}\text { Dimensi Konsep } \\
\text { Smart City }\end{array}$ & Variabel Penelitian \\
\hline \multirow{4}{*}{1.} & \multirow{4}{*}{ Smart Economy } & Jenis dan jumlah industri \\
\hline & & Jenis dan jumlah entrepreneurship \\
\hline & & Kondisi entrepreneurship \\
\hline & & $\begin{array}{l}\text { Adanya kontribusi ekonomi terhadap lingkup } \\
\text { administrasi lainnya }\end{array}$ \\
\hline \multirow{2}{*}{2.} & \multirow{2}{*}{ Smart Mobility } & Kondisi sadar teknologi \\
\hline & & Kondisi penggunaan internet \\
\hline \multirow{2}{*}{3.} & \multirow{2}{*}{ Smart Environment } & Tersedianya sarana (TPS, ruang terbuka bersama) \\
\hline & & Tersedianya prasarana (gerobak sampah, IPAL) \\
\hline \multirow{3}{*}{4.} & \multirow{3}{*}{ Smart People } & Tingkat pendidikan \\
\hline & & Jenis dan jumlah macam kegiatan \\
\hline & & Open mind \\
\hline \multirow{3}{*}{5.} & \multirow{3}{*}{ Smart Living } & Fasilitas kesehatan \\
\hline & & Fasilitas pendidikan \\
\hline & & Kondisi masyarakat \\
\hline \multirow[b]{2}{*}{6.} & \multirow[b]{2}{*}{ Smart Governance } & Jumlah pelayanan pemerintah via online \\
\hline & & $\begin{array}{l}\text { Jumlah pengakses atau pengunjung laman } \\
\text { pelayanan pemerintah }\end{array}$ \\
\hline
\end{tabular}

Berikut merupakan hasil faktor-faktor mana sajakah yang berpengaruh pada kampung perkotaan di Kota Surabaya, dapat dilihat pada gambar berikut.

Tabel 7.

Variabel Berpengaruh pada Kampung Margo Rukun

\begin{tabular}{|c|c|c|c|c|}
\hline Variabel & $\begin{array}{c}\text { Original Sample } \\
(\mathrm{O})\end{array}$ & $\begin{array}{c}\text { Standard } \\
\text { Deviation (STDEV) }\end{array}$ & $\begin{array}{c}\text { T Statistics } \\
(\mid \mathrm{O} / \mathrm{STDEV})\end{array}$ & P Values \\
\hline SEc1 & 0.828 & 0.2 & 4.131 & 0 \\
\hline SEc2 & 0.688 & 0.316 & 2.181 & 0.03 \\
\hline SEc3 & 0.735 & 0.295 & 2.488 & 0.013 \\
\hline SEC4 & 0.785 & 0.249 & 3.146 & 0.002 \\
\hline SEn3 & 1 & 0 & & 0 \\
\hline SG1 & 0.869 & 0.177 & 4.916 & 0 \\
\hline SG2 & 0.799 & 0.19 & 4.202 & 0.002 \\
\hline SG3 & 0.725 & 0.232 & 3.124 & 0.008 \\
\hline SL1 & 0.805 & 0.302 & 2.669 & 0.03 \\
\hline SL2 & 0.745 & 0.342 & 2.178 & 0.034 \\
\hline SL5 & 0.525 & 0.247 & 2.129 & 0.02 \\
\hline SL8 & 0.804 & 0.118 & 6.822 & 0.023 \\
\hline SM1 & 0.94 & 0.404 & 2.325 & \\
\hline SM2 & 0.937 & 0.41 & 2.284 & \\
\hline SP1 & 1 & 0 & & \\
\hline
\end{tabular}

Tabel 7.

Variabel Berpengaruh pada Kampung Lawas Maspati

\begin{tabular}{|c|c|c|}
\hline No & $\begin{array}{l}\text { Dimensi Konsep } \\
\text { Smart City }\end{array}$ & Variabel Penelitian \\
\hline \multirow{4}{*}{1.} & \multirow{4}{*}{ Smart Economy } & Jenis dan jumlah industri \\
\hline & & Kondisi industri \\
\hline & & Jenis dan jumlah entrepreneurship \\
\hline & & Kondisi entrepreneurship \\
\hline \multirow{2}{*}{2.} & \multirow{2}{*}{ Smart Mobility } & Kondisi sadar teknologi \\
\hline & & Kondisi penggunaan internet \\
\hline 3. & Smart Environment & $\begin{array}{l}\text { Adanya koordinasi warga mengenai pengelolaan } \\
\text { lingkungan }\end{array}$ \\
\hline 4. & Smart People & Tingkat pendidikan \\
\hline \multirow{4}{*}{5.} & \multirow{4}{*}{ Smart Living } & Jenis dan jumlah pelaporan terkait kriminalitas \\
\hline & & Kondisi kriminalitas \\
\hline & & Fasilitas bangunan umum \\
\hline & & Kondisi masyarakat \\
\hline \multirow{3}{*}{6.} & \multirow{3}{*}{ Smart Governance } & Jumlah pelayanan pemerintah via online \\
\hline & & $\begin{array}{l}\text { Jumlah pengakses atau pengunjung laman } \\
\text { pelayanan pemerintah }\end{array}$ \\
\hline & & $\begin{array}{l}\text { Kondisi tanggapan masyarakat atas pelayanan } \\
\text { pemerintah via online }\end{array}$ \\
\hline
\end{tabular}

Berdasarkan hasil tabel diatas, diketahui bahwa lokasi studi sangat mempengaruhi variabel penelitian yang berpengaruh. Dimana variabel terpilih dapat menjadi gambaran umum mengenai karakter kampung perkotaan di Kota Surabaya [9].

\section{KESIMPULAN}

Pada penelitian ini bertujuan untuk menentukan variabel berpengaruh terhadap pengembangan kampung cerdas dalam mewujudkan konsep smart city. Berikut ini merupakan hasil yang diperoleh dari penelitian ini:

1. Variabel berpengaruh yang didapatkan menggambarkan karakter masing-masing, dimana perlu disesuaikan pengembangan kampung perkotaan sesuai dengan karakter dari sebuah kawasan.

2. Kampung Margo Rukun memiliki variabel berpengaruh sebagai berikut. Jenis dan jumlah industri, kondisi industri, jenis dan jumlah entrepreneurship, kondisi entrepreneurship, adanya kontribusi ekonomi terhadap lingkup administrasi lainnya, kondisi sadar teknologi, kondisi penggunaan internet, tersedianya sarana, tersedianya prasarana, tingkat pendidikan, jenis dan jumlah macam kegiatan, open mind, fasilitas kesehatan, fasilitas pendidikan, kondisi masyarakat, jumlah pelayanan pemerintah via online, serta jumlah pengakses atau pengunjung laman pelayanan pemerintah.

3. Kampung Lawas Maspati memiliki variabel berpengaruh sebagai berikut. Jenis dan jumlah industri, kondisi industri, jenis dan jumlah entrepreneurship, kondisi entrepreneurship, kondisi sadar teknologi, kondisi penggunaan internet, adanya koordinasi warga kondisi kriminalitas, fasilitas bangunan umum, kondisi masyarakat, jumlah pelayanan pemerintah via online, jumlah pengakses atau pengunjung laman pelayanan pemerintah, serta kondisi tanggapan masyarakat atas pelayanan pemerintah via online.

\section{DAFTAR PUSTAKA}

[1] Konvergensi Agenda Pembangunan. 2015.

[2] C. A. Bintang, "Analisis Strategi Penataan Permukiman dan Infrastruktur di Kabupaten Pelalawan," J. Saintis, vol. 14, p. Nomor 1 April 2014 70-81 ISSN: 1410-7783, 2014.

[3] R. Albino, Vito. Berardi, Umberto. Maria.D, "Smart Cities: Definitons, Dimensions, Perfomance, and Initiatives,Journal of Urban Technoogy," vol. 1, pp. 3-21, 2015.

[4] D. Junara, Nunik. Eka Putrie, Yulia. Rahmawati, Kegiatan Ekonomi Dan Kualitas Pemukiman Di Kampung Keputran Kejambon Surabaya. 2010.

[5] Pemerintah Kota Surabaya, Kampung Surabaya Menuju Abad 21, Kajian Penataan dan Revitalisasi Kampung di Surabaya. 2012.

[6] Department of Spatial Planning, "No Title," 2016. [Online]. Available: http://smart-cities.eu/.

[7] A. V. Monica, Penentuan Indikator Remunerasi Berdasarkan Persepsi Dosen di Lingkungan FMIPA ITS Dengan Structural Equation Modeling Partial Least Square (SEM-PLS) Dan Pls Prediction-Oriented Segmentation (PLS-POS). 2017.

[8] D. Cahyani, Reny. Rahmawati, Peningkatan Partisipasi Masyarakat Dalam Perbaikan Sanitasi Permukiman Kelurahan Putat Jaya Kota Surabaya. 2016.

[9] D. Paramasatya, Penentuan Kriteria Pengembangan Kampung Cerdas di Kota Surabaya dalam Mewujudkan Konsep Smart City. 2017. 